\title{
PENINGKATAN KOMPETENSI GURU DALAM MEMBEDAH SKL (STANDAR KOMPETENSI LULUSAN) MELALUI KEGIATAN WORKSHOP
}

\author{
Kaswidarsof \\ Kepala UPTD SD Negeri 12 Guguak VIII Koto, \\ Kecamatan Guguak, Kabupaten Lima Puluh Kota \\ email: kaswidarsof.wid65@gmail.com
}

\begin{abstract}
This study was aimed to determine the increasing in teachers' competence in reviewing SKL (graduation competency standards) through workshops at SD Negeri 05 Koto Baru Simalanggang for the 2018/2019 academic year. This type of research was School Action Research (PTS) which consists of two cycles. The research location was SD Negeri 05 Koto Baru Simalanggang, Payakumbuh District, Lima Puluh Kota Regency. The research subjects were 7 teachers of SD Negeri 05 Koto Baru Simalanggang. The instruments in this study were the teachers' activity observation sheet instrument, the SKL surgical assessment instrument. The findings obtained that the teacher's average score in dissecting SKL in the first cycle was 70.84 and was included in the sufficient criteria. Because the success indicators had not yet been achieved, the research was continued to cycle II. In the second cycle it was known that the teacher's average score in dissecting SKL was 89.50 and it was included in the good criteria. Because the average score of the teacher's SKL surgery in cycle II had reached the predetermined success indicators, so the research was not continued to the next cycle.The results showed that there was an increase in teacher competence in dissecting SKL through workshops at SDN 05 Koto Baru for the 2018/2019 academic year.
\end{abstract}

Keywords: Teacher Competence, SKL, workshop

\begin{abstract}
ABSTRAK
Penelitian ini bertujuan untuk mengetahui peningkatan kompetensi guru dalam membedah SKL (Standard Kompetensi Lulusan) melalui kegiatan workshop di SD Negeri 05 Koto Baru Simalanggang tahun pelajaran 2018/2019. Jenis penelitian ini adalah Penelitian Tindakan Sekolah (PTS) yang terdisri dari dua siklus. Tempat penelitian yaitu SD Negeri 05 Koto Baru Simalanggang Kecamatan Payakumbuh, Kabupaten Lima Puluh Kota. Subjek penelitian yaitu 7 orang guru SD Negeri 05 Koto Baru Simalanggang. Instrumen dalam penelitian ini yaitu instrumen lembar observasi kegiatan guru, instrumen penilaian bedah SKL. Temuan yang diperoleh nilai rata-rata guru dalam membedah SKL pada siklus I sebesar 70,84 dan masuk dalam kriteria cukup. Karena masih belum mencapai indikator keberhasilan yang telah ditetapkan maka penelitian dilanjutkan ke siklus II. Pada siklus II diketahui bahwa nilai rata-rata guru dalam membedah SKL yaitu 89,50 dan masuk dalam kriteria baik. Karena nilai rata-rata bedah SKL guru pada siklus II sudah mencapai indikator keberhasilan yang telah ditetapkan sehingga penelitian tidak dilanjutkan ke siklus berikutnya. Hasil penelitian menunjukkan bahwa terjadi peningkatan kompetensi guru dalam
\end{abstract}


membedah SKL melalui kegiatan workshop di SDN 05 Koto Baru tahun pelajaran 2018/2019.

Kata kunci: Kompetensi Guru, SKL, workshop

\section{PENDAHULUAN}

Keberhasilan suatu sekolah dalam mencapai tujuan yang diharapkan sangatlah tergantung pada bagaimana model pengelolaan terhadap segala sumber daya yang dimiliki sekolah tersebut. Walaupun sumber daya sekolah yang memadai bukan jaminan untuk mewujudkan harapan-harapan warga sekolah, yang telah diteruskan menjadi tujuan sekolah. Jika kepala sekolah sebagai pimpinan tidak mampu melaksanakan tugas pokoknya dan fungsinya dengan baik.

Banyak tugas-tugas baru kepala sekolah yang profesional, tentu tidaklah mudah. Diperlukan waktu yang cukup untuk belajar bagaimana melaksanakan tugas-tugas baru tersebut. Peraturan Menteri Pendidikan Nasional Nomor 13 tahun 2007 tentang standar kompetensi kepala sekolah/madrasah yaitu kompetensi kepribadian, manajerial, kewirausahaan, supervisi dan kompetensi sosial. Dengan adanya pengembangan kompetensi kepala sekolah menejerial, kewirausahaan, dan supervisi. Selain sebagai pemimpin, kepala sekolah juga merupakan manajer, yang dituntut memiliki kemampuan manajerial terkait dengan terwujudnya sekolah yang efektif. Kepala sekolah diberi tugas tambahan untuk menuju dan mengelola sekolah dalam upaya meningkatkan mutu dan kualitas sekolah yang dipimpinnya. Adanya tugas tambahan tersebut seorang kepala sekolah harus dapat menjadi guru yang kreatif dan selalu melakukan inovasi dalam pembelajaran.

Berdasarkan kenyataan yang ada dilapangan prestasi kelulusan siswa kelas VI masih jauh dari yang diharapkan, walaupun secara kuantitas lulus seratus persen. Permasalahan lainnya yaitu kurangnya kemampuan guru dalam membuat kisi-kisi kegiatan bedah SKL, teknik penulisan soal, dan hal yang penting dalam penulisan soal. Berdasarkan latar belakang yang diuraikan diatas maka penulis melakukan tindakan dengan melaksanakan kegiatan workshop dengan mengundang narasumber yaitu pengawas sekolah.

Purwanto (1984: 107) menyatakan workshop merupakan suatu kegiatan yang dilakukan untuk mengembangkan kesanggupan berpikir dan bekerja bersama-sama secara kelompok ataupun bersifat perseorangan untuk membahas dan memecahkan segala permasalahan yang ada baik mengenai masalah-masalah yang bersifat teoritis maupun yang bersifat raktis dengan tujuan untuk dapat meningkatkan kualitas kompetensi pedagogik guru sehingga dapat menyelesaikannya sesuai tugas masing-masing. Oleh karena itu, diharapkan dengan adanya worshop dapat meningkatkan kompetensi guru dalam membedah SKL.

Penelitian ini bertujuan untuk mengetahui peningkatan kompetensi guru dalam membedah SKL (standar kompetensi kelulusan) melalui kegiatan workshop di SD Negeri 05 Koto Baru Simalanggang tahun pelajaran 2018/2019. Hasil penelitian tindakan sekolah diharapkan memberi manfaat antara lain:

1. Manfaat tertulis

a. Memberikan sumbangan pemikiran untuk peningkatan kemampuan guru membedah SKL di SDN 05 Koto Baru Simalanggang. 
b. Memberikan sumbangan ilmiah dalam ilmu pendidikan sekolah dasar dengan peningkatan kemampuan guru dalam membedah SKL di SDN 05 Koto Baru Simalanggang.

c. Sebagai pijakan dan referensi pada penelitian-penelitian selanjutnya yang berhubungan dengan peningkatan kemampuan guru dalam membedah SKL edi SDN 05 Koto Baru Simalanggang.

2. Manfaat Praktis

a. Bagi Guru

1) Meningkatkan kemampuan guru dalam membedah SKL.

2) Meningkatkan kompetensi guru.

b. Bagi Sekolah

1) Menambahkan pengetahuan dan wawasan dalam peningkatan prestasi siswa dan kualitas sekolah.

2) Memberikan bimbingan dan masukan dalam meningkatkan aktifitas dewan guru sebagai perbaikan sekolah.

3) Meningkatkan prestasi dan profesionalitas lembaga dalam penyelenggaraan pendidikan.

\section{METODOLOGI}

Jenis penelitian ini adalah Penelitian Tindakan Sekolah (PTS) yang terdisri dari dua siklus. Tempat penelitian yaitu SD Negeri 05 Koto Baru Simalanggang Kecamatan Payakumbuh, Kabupaten Lima Puluh Kota. Subjek penelitian yaitu 7 orang guru SD Negeri 05 Koto Baru Simalanggang. Rancangan PTS yang digunakan adalah model Kemmis dan Mc.Tanggart (depsiknas,2004), yang meliputi 4 alur (langkah) yaitu perencanaan tindakan, pelaksanaan tindakan, pengamatan dan refleksi. Penelitian ini dilaksanakan dalam dua siklus. Instrumen dalam penelitian ini yaitu instrumen lembar observasi kegiatan guru, instrumen penilaian bedah SKL. Dalam membedah SKL guru dibagi menjadi tiga kelompok mata pelajaran. Uraian mata pelajaran Bahasa Indonesia Nelda Yusni, S.Pd.SD dan Desmawati, S.Pd, mata pelajaran IPA Zasmawirda dan Ratih Suciati, S.Pd.I, Sedangkan mata pelajaran Matematika Musniati, S.Pd.SD dan Yulferiati,S.Pd.I dan Fitria Yunida. Teknik analisis data yang digunakan yaitu mencari rata-rata dan teknik persentase.

Tabel 1. Kriteria Penilaian

\begin{tabular}{|c|c|}
\hline Interval Nilai & Kriteria \\
\hline $90 \leq$ Nilai $\leq 100$ & Amat Baik (A) \\
\hline $75 \leq$ Nilai $<90$ & Baik (B) \\
\hline $60 \leq$ Nilai $<75$ & Cukup (C) \\
\hline $0 \leq$ Nilai $<60$ & Kurang (K) \\
\hline
\end{tabular}

Indikator keberhasilan dalam penelitian ini adalah apabila nilai membedah SKL guru secara berkelompok sudah mencapai nilai minimal Baik.

\section{HASIL PENELITIAN DAN PEMBAHASAN}

\section{Siklus 1}

\section{a. Perencanaan}

Tahap perencanaan dilakukan pada tanggal 21 Juli 2018 pukul 08.00, diruang kepala sekolah. Hal-hal yang direncanakan yaitu:

1) Menentukan dan menghubungi narasumber. 
2) Menginformasikan ke guru kegiatan workshop.

3) Membuat susunan acara work shop.

4) Mempersiapkan pembagian kelompok guru untuk setiap mata pelajaran.

5) Mempersiapkan tugas yang akan diberikan kepada guru.

6) Mempersiapkan jadwal.

7) Mempersiapkan instrumen penelitian.

b. Pelaksanaan

Pertemuan pertama siklus I yaitu tahap pelaksanaan workshop bedah SKL dilakukan pada hari Sabtu tanggal 28 Juli 2018 pukul 08.30 WIB sampai selesai dengan narasumber yaitu pengawas sekolah Ibu Endryati, S.Pd. Langkah-langkah pelaksanaan kegiatan workshop bedah SKL yaitu:

1) Protokol membuka acara workshop.

2) Sepatah kata dari pengawas.

3) Sambutan dari kepala sekolah sebagai peneliti.

4) Penyampaian materi oleh narasumber.

5) Diskusi

6) Membagi guru sesuai kelompok mata pelajaran.

7) Tiap guru dalam kelompok membuat soal-soal sesuai dengan indikator dan kisi-kisi.

8) Menutup kegiatan.

Pertemuan kedua dilakukan pada hari Sabtu tanggal 4 Agustus 2018. Pertemuan kedua ini guru melanjutkan diskusi kelompok. Kegiatan ini dengan bimbingan dan pantauan dari peneliti. Di akhir kegiatan ini guru mengumpulkan hasil kerja kelompok. Langkah-langkah pertemuan kedua adalah sebagai berikut:

1) Meminta guru duduk sesuai kelompok mata pelajaran.

2) Meminta guru melanjutkan kerja kelompok sebelumnya mengenai membuat soal-soal sesuai dengan indikator dan kisi-kisi.

3) Mengumpulkan hasil kerja kelompok.

Data dibawah ini merupakan skor perolehan dari 7 orang guru yang dibagi dalam 3 kelompok. Hasil Siklus I dapat dilihat sebagai berikut:

Tabel 2. Hasil Siklus I Bedah SKL kelas VI Pada Mata Pelajaran Bahasa Indonesia, IPA dan Matematika di SDN 05 Koto Baru Simalanggang

\begin{tabular}{|l|l|c|}
\hline \multirow{2}{*}{ NO } & \multicolumn{1}{|c|}{ Kelompok } & NILAI \\
& & \\
\hline 1 & Bahasa Indonesia & 62,50 \\
\hline 2 & IPA & 68,78 \\
\hline 3 & Matematika & 81,25 \\
\hline JUMLAH & 212,53 \\
\hline RATA-RATA & 70,84 \\
\hline NILAI TERENDAH & 62,50 \\
\hline NILAI TERTINGGI & 81,25 \\
\hline KRITERA & Cukup \\
\hline
\end{tabular}


Pada siklus I diketahui bahwa nilai yang dicapai oleh guru adalah nilai terendah yaitu 62,50; nilai tertinggi yaitu 81,25 , dengan jumlah 212,53 , rata-rata 70,84 dan masuk dalam kriteria cukup. Berikut dapat dilihat jumlah perolehan nilai bedah SKL pada masing-masing interval nilai pada diagram 1.

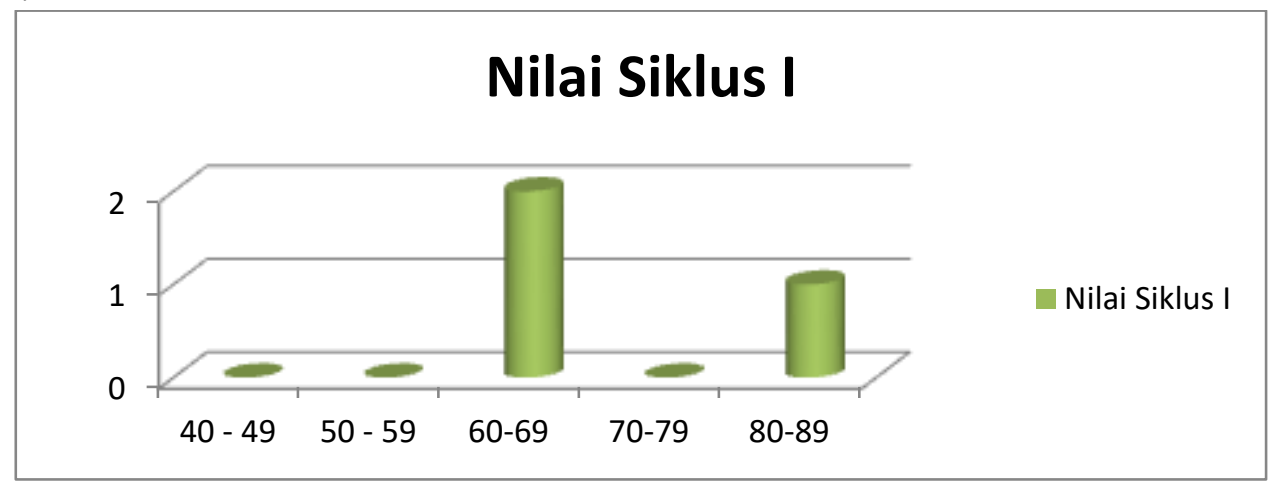

\section{Diagram 1. Nilai Siklus I Bedah SKL di SDN 05 Koto Baru Simalanggang.}

c. Pengamatan

Pengamatan yang dilakukan terhadap aktivitas guru pada siklus I adalah sebagai berikut.

Tabel 3. Data Pengamatan Aktivitas Guru pada Siklus I

\begin{tabular}{|c|c|c|c|}
\hline \multirow{2}{*}{ NO } & \multirow{2}{*}{ URAIAN KEGIATAN } & \multicolumn{2}{|c|}{$\underline{\text { SKOR }}$} \\
\hline & & Pert. 1 & Pert. 2 \\
\hline 1 & Kerjasama guru dalam bekerja & 3 & 4 \\
\hline 2 & $\begin{array}{l}\text { Kedisiplinan peserta dalam } \\
\text { mengikuti pembelajaran }\end{array}$ & 3 & 3 \\
\hline 3 & $\begin{array}{l}\text { Mempunyai rasa tanggung jawab } \\
\text { dalam mengerjakan tugas }\end{array}$ & 3 & 4 \\
\hline 4 & $\begin{array}{l}\text { Menggunakan bahasa yang jelas } \\
\text { dalam berkomunikasi sesama } \\
\text { teman }\end{array}$ & 3 & 3 \\
\hline 5 & $\begin{array}{lrr}\begin{array}{l}\text { Keantusiasan } \\
\text { mengikuti }\end{array} & \begin{array}{r}\text { peserta } \\
\text { kegiatan }\end{array} & \text { dalam } \\
\text { berlangsung } & & \\
\end{array}$ & 3 & 4 \\
\hline 6 & $\begin{array}{l}\text { Dapat menyelesaikan tugas } \\
\text { dengan baik }\end{array}$ & 3 & 4 \\
\hline 7 & $\begin{array}{l}\text { Bisa memanfaatkan waktu yang } \\
\text { disediakan panitia }\end{array}$ & 3 & 3 \\
\hline 8 & $\begin{array}{l}\text { Memberikan kesempatan pada } \\
\text { teman untuk mengeluarkan } \\
\text { pendapat }\end{array}$ & 3 & 3 \\
\hline 9 & $\begin{array}{l}\text { Bisa memanfaatkan bahan yang } \\
\text { disediakan fasilisator }\end{array}$ & 2 & 3 \\
\hline 10 & menyelesaian & 2 & 3 \\
\hline
\end{tabular}




\begin{tabular}{|c|l|c|c|}
\hline \multirow{2}{*}{ NO } & \multirow{2}{*}{ URAIAN KEGIATAN } & \multicolumn{2}{|c|}{ SKOR } \\
\cline { 3 - 4 } & & Pert. 1 & Pert.2 \\
\hline \multirow{2}{*}{ Jumlah } & 28 & 34 \\
\hline \multicolumn{2}{|c|}{ Persentase } & $70.00 \%$ & $\mathbf{8 5 . 0 0 \%}$ \\
\hline
\end{tabular}

Dari tabel diatas terlihat terjadi peningkatan aktivitas guru dalam membedah SKL. Pada pertemuan pertama siklus I persentase aktivitas guru sebesar $70 \%$, dan pada pertemuan kedua sebesar $85 \%$. Terjadi peningkatan sebesar $15 \%$ dari pertemuan pertama ke pertemuan kedua.

d. Refleksi

Setelah dilakukan kegiatan workshop dan bedah SKL dilakukan dan guru menyelesaikan tugasnya. Berdasarkan tugas guru dalam membedah SKL terlihat bahwa terjadi peningkatan kemampuan guru dalam membedah SKL dari sebelum tindakan dilakukan. Nilai rata-rata guru dalam membedah SKL pada siklus I yaitu sebesar 70,84 dan masuk dalam kriteria cukup. Oleh karena itu, peneltian masih dilanjutkan ke siklus berikutnya karena indikator keberhasilan penelitian belum tercapai. Sehingga perlu dilakukan beberapa perbaikan pada siklus II. Perbaikan yang dilakukan adalah kepala sekolah kembali mengumpulkan guru, dan memberikan arahan mengenai bedah SKL.

\section{Siklus 2}

a. Perencanaan

Perencanaan yang dilakukan pada siklus II adalah sebagai berikut.

1) Mempersiapkan perbaikan terhadap hasil siklus I yang kurang bersama guru.

2) Mempersiapkan jadwal.

3) Mempersiapkan instrumen penelitian.

b. Pelaksanaan

Pertemuan pertama siklus II yaitu tahap pelaksanaan dilakukan pada hari Sabtu tanggal 11 Agustus 2018 pukul 10.00 WIB sampai dengan 12.30 WIB. Langkah-langkah pelaksanaan kegiatan yaitu sebagai berikut:

1) Membuka kegiatan

2) Kepala sekolah memberikan ulasan dan perbaikan apa yang harus dilakukan guru berdasarkan hasil siklus I.

3) Membagi guru sesuai kelompok mata pelajaran.

4) Tiap guru dalam kelompok memperbaiki dan membuat soal-soal sesuai dengan indikator dan kisi-kisi.

5) Menutup kegiatan.

Pertemuan kedua dilakukan pada hari Sabtu tanggal 26 Agustus 2018. Pertemuan kedua ini guru melanjutkan diskusi kelompok. Kegiatan ini dengan bimbingan dan pantauan dari peneliti. Di akhir kegiatan ini guru mengumpulkan hasil kerja kelompoknya.

Data dibawah ini merupakan skor perolehan dari 7 orang guru yang dibagi dalam 3 kelompok. Hasil Siklus II dapat dilihat sebagai berikut: 
Tabel 4. Hasil Siklus II Bedah SKL kelas VI Pada Mata Pelajaran Bahasa Indonesia, IPA dan Matematika di SDN 05 Koto Baru Simalanggang

\begin{tabular}{|c|c|c|}
\hline NO & Kelompok & NILAI \\
\hline 1 & Bahasa Indonesia & 81,25 \\
\hline 2 & IPA & 87,50 \\
\hline 3 & Matematika & 93,97 \\
\hline \multicolumn{2}{|c|}{ JUMLAH } & 268,50 \\
\hline \multicolumn{2}{|c|}{ RATA-RATA } & 89,50 \\
\hline \multicolumn{2}{|c|}{ NILAI TERENDAH } & 81,25 \\
\hline \multicolumn{2}{|c|}{ NILAI TERTINGGI } & $\mathbf{9 3 , 9 7}$ \\
\hline \multicolumn{2}{|c|}{ Kriteria } & Baik \\
\hline
\end{tabular}

Pada siklus II diketahui bahwa nilai yang dicapai oleh guru adalah nilai terendah yaitu 81,25; nilai tertinggi yaitu 93,97, dengan jumlah 268,50, rata-rata 89,50 dan masuk dalam kriteria baik. Berikut dapat dilihat jumlah perolehan nilai bedah SKL pada masing-masing interval nilai pada diagram 2.

\section{Nilai Siklus II}

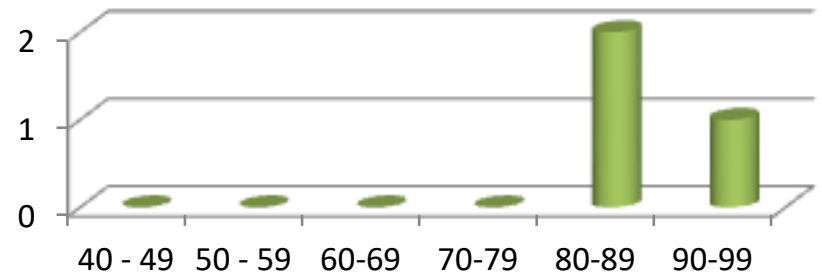

Nilai Siklus II

Diagram 2. Nilai Siklus II Bedah SKL di SDN 05 Koto Baru Simalanggang

c. Pengamatan

Selama pelaksanaan tindakan peneliti mengamati aktivitas guru, dengan hasil aktivitas guru pada siklus II adalah sebagai berikut.

Tabel 5. Data Pengamatan Aktivitas Guru pada Siklus II

\begin{tabular}{|c|l|c|c|}
\hline \multirow{2}{*}{ NO } & \multicolumn{1}{|c|}{ URAIAN KEGIATAN } & \multicolumn{2}{|c|}{ SKOR } \\
\cline { 3 - 4 } & \multicolumn{1}{|c|}{ Pert. 1 } & Pert.2 \\
\hline 1 & Kerjasama guru dalam bekerja & 4 & 4 \\
\hline 2 & $\begin{array}{l}\text { Kedisiplinan peserta dalam } \\
\text { mengikuti pembelajaran }\end{array}$ & 4 & 4 \\
\hline 3 & $\begin{array}{l}\text { Mempunyai rasa tanggung jawab } \\
\text { dalam mengerjakan tugas }\end{array}$ & 4 & 4 \\
\hline
\end{tabular}




\begin{tabular}{|c|l|c|c|}
\hline \multirow{2}{*}{ NO } & \multicolumn{1}{|c|}{ URAIAN KEGIATAN } & \multicolumn{2}{|c|}{ SKOR } \\
\cline { 3 - 4 } & \multicolumn{1}{|c|}{$\begin{array}{c}\text { Pert. 1 } \\
\text { Penggunakan bahasa yang jelas } \\
\text { dalam berkomunikasi sesama } \\
\text { teman }\end{array}$} & 3 & 4 \\
\hline 5 & $\begin{array}{l}\text { Keantusiasan peserta dalam } \\
\text { mengikuti kegiatan yang } \\
\text { berlangsung }\end{array}$ & 4 & 4 \\
\hline 6 & $\begin{array}{l}\text { Dapat menyelesaikan tugas } \\
\text { dengan baik }\end{array}$ & 4 & 4 \\
\hline 7 & $\begin{array}{l}\text { Bisa memanfaatkan waktu yang } \\
\text { disediakan panitia }\end{array}$ & 3 & 4 \\
\hline 8 & $\begin{array}{l}\text { Memberikan kesempatan pada } \\
\text { teman untuk mengeluarkan } \\
\text { pendapat }\end{array}$ & 4 & 4 \\
\hline 9 & $\begin{array}{l}\text { Bisa memanfaatkan bahan yang } \\
\text { disediakan fasilisator }\end{array}$ & 4 & 4 \\
\hline 10 & $\begin{array}{l}\text { Bersama-sama menyelesaian } \\
\text { bedah SKL }\end{array}$ & 3 & $\mathbf{4 0}$ \\
\hline & $\begin{array}{l}\text { Jumlah } \\
\text { Persentase }\end{array}$ & $\mathbf{9 2 . 5 0 \%}$ & $\mathbf{1 0 0 . 0 0 \%}$ \\
\hline
\end{tabular}

Dari tabel diatas terlihat terjadi peningkatan aktivitas guru dalam membedah SKL. Pada pertemuan pertama siklus II persentase aktivitas guru sebesar $92,50 \%$, dan pada pertemuan kedua sebesar $100 \%$. Terjadi peningkatan sebesar $17,5 \%$ dari pertemuan pertama ke pertemuan kedua.

d. Refleksi

Pada siklus II terjadi peningkatan nilai guru dalam membedah SKL dari pertemuan pertama ke pertemuan kedua. Nilai guru dari siklus I juga mengalami peningkatan dalam membedah SKL. Pada siklus II ini rata-rata nilai guru dalam membedah SKL yaitu sebesar 89,50 dan masuk dalam kriteria baik. Karena indikator keberhasilan penelitian sudah tercapai, maka penelitian tidak perlu dilanjutkan ke siklus berikutnya.

\section{Pembahasan}

Temuan yag diperoleh dari penelitian yaitu pada siklus I diketahui bahwa nilai yang dicapai oleh guru adalah nilai terendah yaitu 62,50; nilai tertinggi yaitu 81,25 , dengan jumlah 212,53 , rata-rata 70,84 dan masuk dalam kriteria cukup. Karena masih belum mencapai indikator keberhasilan yang telah ditetapkan maka penelitian dilanjutkan ke siklus II. Pada siklus II diketahui bahwa nilai yang dicapai oleh guru adalah nilai terendah yaitu 81,25; nilai tertinggi yaitu 93,97, dengan jumlah 268,50, rata-rata 89,50 dan masuk dalam kriteria baik. Pada siklus II nilai rata-rata bedah SKL guru sudah mencapai indikator keberhasilan yang telah ditetapkan sehingga penelitian tidak dilanjutkan ke siklus berikutnya. Ditinjau dari setiap kelompok mata pelajaran juga jelas terlihat terjadinya 
peningakatan kemampuan guru dalam membedah SKL seperti terlihat pada diagram 3 berikut.

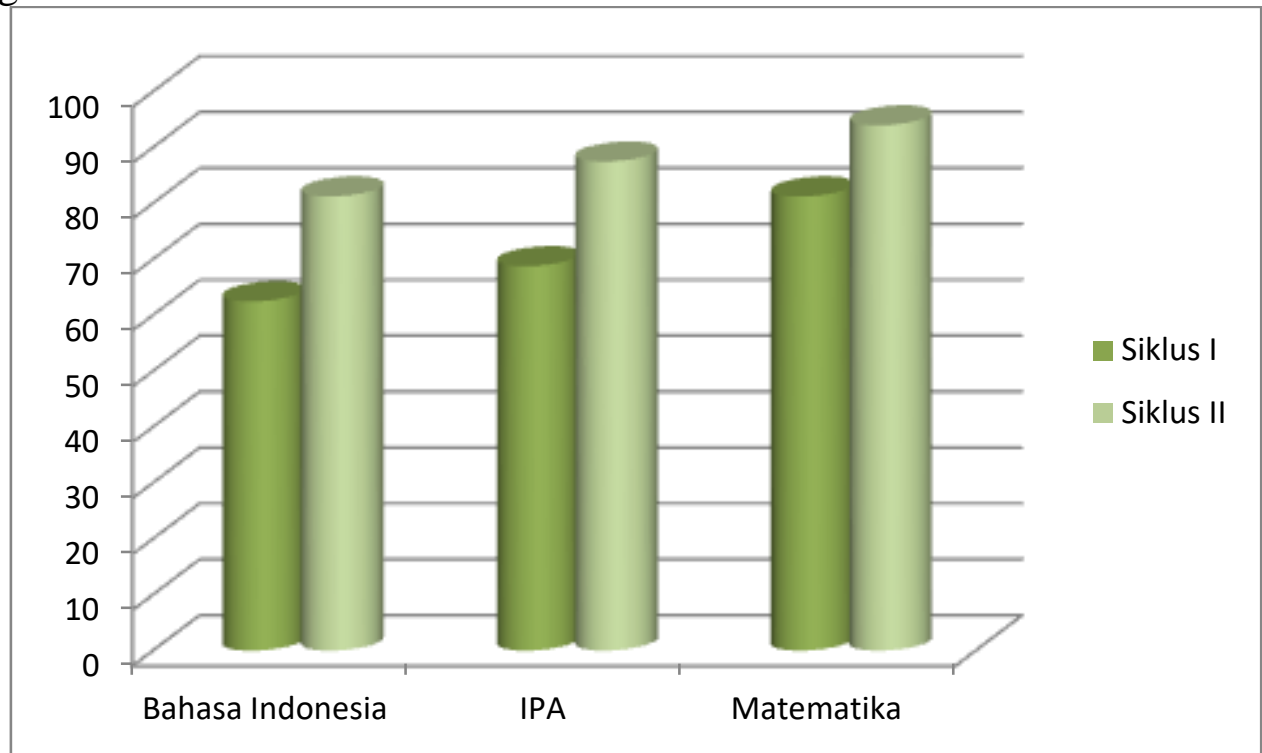

\section{Diagram 3. Peningkatan Nilai Membedah SKL Setiap Kelompok Mata Pelajaran}

Jika ditinjau dari aktivitas guru dalam kegiatan membedah SKL juga terjadi peningkatan. Pada pertemuan pertama siklus I persentase aktivitas guru sebesar $70 \%$, dan pada pertemuan kedua sebesar 85\%. Terjadi peningkatan sebesar $15 \%$ dari pertemuan pertama ke pertemuan kedua. Pada siklus II terjadi peningkatan aktivitas guru dalam membedah SKL setiap pertemuan. Pada pertemuan pertama siklus II persentase aktivitas guru sebesar 92,50\%, dan pada pertemuan kedua sebesar $100 \%$. Terjadi peningkatan sebesar $17,5 \%$ dari pertemuan pertama ke pertemuan kedua. Peningkatan aktivitas guru dalam membdah SKL setiap pertemuan dapat terlihat pada diagram 4 berikut ini.

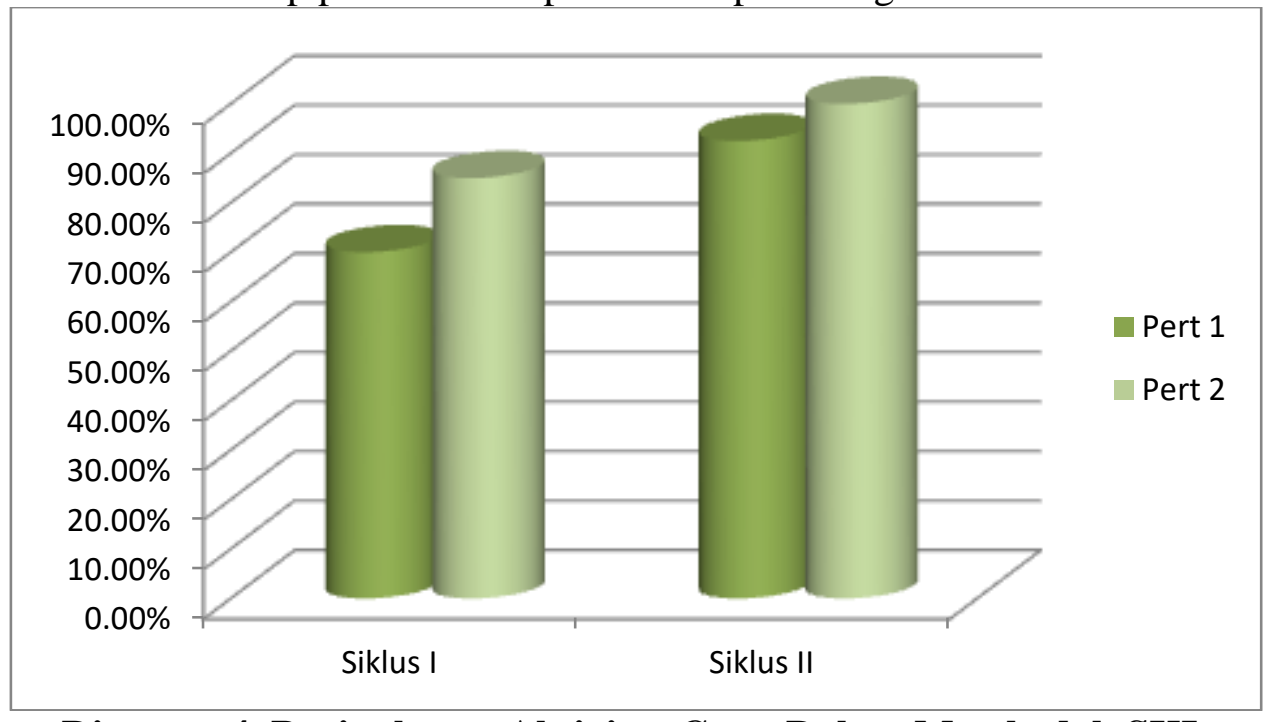

Diagram 4. Peningkatan Aktivitas Guru Dalam Membedah SKL

Berdasarkan pembahasan diatas terlihat bahwa terjadi peningkatan nilai rata-rata guru dalam membedah SKL. Kriteria guru dlam membedah SKL pada siklus I dalam kategori cukup meningkat menjadi kategori baik pada siklus II. 
Sehingga kompetensi guru dalam membedah SKL juga meningkat. Dapat dikatakan bahwa terjadi peningkatan kompetensi guru dalam membedah SKL melalui kegiatan workshop di SDN 05 Koto Baru tahun pelajaran 2018/2019.

\section{KESIMPULAN DAN SARAN}

Dengan melaksanakan bedah SKL melalui workshop yang bertujuan untuk peningkatan kompetensi guru dalam membedah SKL yang juga bertujuan untuk meningkatkan kualitas kelulusan siswa kelas VI di SD Negeri 05 Koto Baru Simalanggang. Pelaksanaan bedah SKL kelas VI melalui workshop yang tepat dan optimal membantu guru untuk meningkatkan mutu kelulusan disuatu sekolah. Dari hasil pelaksanaan bedah SKL melalui workshop yang telah dilaksanakan dapat meningkatkan pemahaman guru dalam pengembangan dan peningkatan standar kelulusan siswa di SD Negeri 05 Koto Baru Simalanggang, Kecamatan Payakumbuh, Kabupaten Lima Puluh Kota. Sehingga dari temuan penelitian dapat disimpulkan bahwa terjadi peningkatan kompetensi guru dalam membedah SKL melalui kegiatan workshop di SDN 05 Koto Baru tahun pelajaran 2018/2019.

Saran yang dapat dikemukakan dari penelitian ini yaitu:

1. Sebaiknya kepala sekolah harus menguasai langkah-langkah pelaksanaan membedah SKL, karena kepala sekolah dapat meningkatkan kinerja guru dalam meningkatkan mutu kelulusan di SDN 05 Koto Baru Simalanggang.

2. Sebaiknya sekolah dapat melaksanakan workshop lainnya, sehingga dapat meningkatkan mutu kepala sekolah, mutu guru, dan sekolah.

3. Penelitian ini dilakukan dengan mengelompokkan guru dalam membedah SKL, peneliti selanjutnya dapat melakukan dengan memberikan penugasan secara individu bagi guru dalam membedah SKL.

\section{DAFTAR PUSTAKA}

Depdiknas 2004. Standar Kompetensi Guru Sekolah Dasar. Jakarta: Depdiknas.

Menteri Pendidikan Nasional. 2007. Peraturan Menteri Pendidikan Nasional No 13 Tahun 2007 Tentang Standar Kompetensi Kepala Sekolah

Purwanto, M. Ngalim dkk. 1984. Administrasi Pendidikan. Jakarta: Mutiara. 